\title{
サロマ湖第二湖口周辺の漂砂特性への気象変化の影響
}

\section{Influence of the Climate Change on Sediment Transport around the Second Inlet of Saloma Lake}

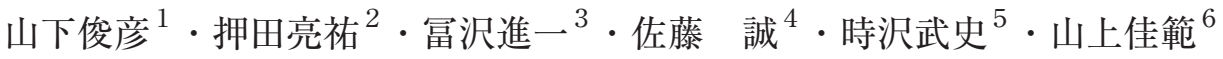 \\ Toshihiko YAM A SHITA, Ryosuke OSHIDA, Shinichi TOMISAWA, Makoto SATO \\ Takeshi TOKISAWA and Yoshinori YAMAGAM I
}

\begin{abstract}
The second inlet of Saloma Lake was made in 1979, and was closed by sand transport at first time at J anuary 2012. The characteristics of topography change from 2001 to 2012 around the Inlet were understood. Primary factors of this closing phenomenon are the increase of long shore sediment transport towards left caused by waves, and the increase of discharged sediment from Tokoro River. The increase of discharged sediment was caused by increasing rain fall because of the global warming, and this phenomenon is happening in a long term. The change of ocean wave direction can be estimated by the change of sun spot number with about ten years period.
\end{abstract}

\section{1はじめに}

サロマ湖はオホーツク海沿岸に位置する国内最大の感 潮湖であり, 湖内はホ夕テや牡蠣の養殖が盛んである. サロマ湖とオホーツク海は, 図-1の様に第一湖口と第二 湖口の二つの湖口により繋がっている。この二つの湖口 は海水交換による湖内の豊かな生態系維持や船舶の航行 に重要である。

第一湖口（防砂堤幅570m）については安定した湖口維 持や浅瀬の形成の抑制を検討するため楠山ら（2007）や 山上ら（2012）により現地観測や数值解析モデルの開発 が行われ, 第一湖口周辺の地形変化特性の把握と, 地形 変化予測がかなりの精度で可能となっている.

一方第二湖口は, 図-1の様に第一湖口と比べて水路幅 $50 \mathrm{~m}$, 防砂堤幅 $75 \mathrm{~m}$ と狭く, 防砂堤の長さも $100 \mathrm{~m}$ と短い にも関わらず，1979年の開削以来最近まで33年間一度も 閉塞等の土砂堆積の問題は発生しなかった. しかし, 2012年1月に初めて閉塞が発生した.

そこで本研究では，まず現地観測デー夕を基に，第二 湖口周辺の漂砂特性と閉塞要因を明らかにする. 次に, 漂砂外力としての波浪特性, 漂砂境界条件としての常呂 川（図-1参照）の河川流出土砂量への気象変化の影響を 検討し, 今後の第二湖口周辺の漂砂特性の予測を試みる.

\begin{tabular}{|c|c|c|}
\hline 1 正会員 & 工博 & 北海道大学大学院工学研究院 \\
\hline 2 学生会員 & & 北海道大学大学院工学院 \\
\hline 3 & & $\begin{array}{l}\text { 北海道開発局網走開発建設部網走港湾事 } \\
\text { 務所 }\end{array}$ \\
\hline 4 正会員 & 工修 & (株) アルファ水工コンサルタンツ \\
\hline 5 & 理修 & (一社) 寒地港湾技術研究センター \\
\hline 6 正会員 & 工博 & (一社) 寒地港湾技術研究センター \\
\hline
\end{tabular}

\section{2 現地データの概要}

サロマ湖第二湖口周辺の深浅測量は2000年11月より現 在まで年一回10月あるいは11月に実施されている。波浪 観測データは, 第二湖口から比較的近く正確な波向き

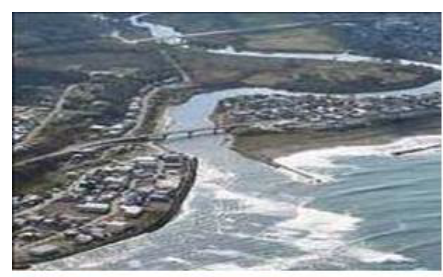

常呂川河口部
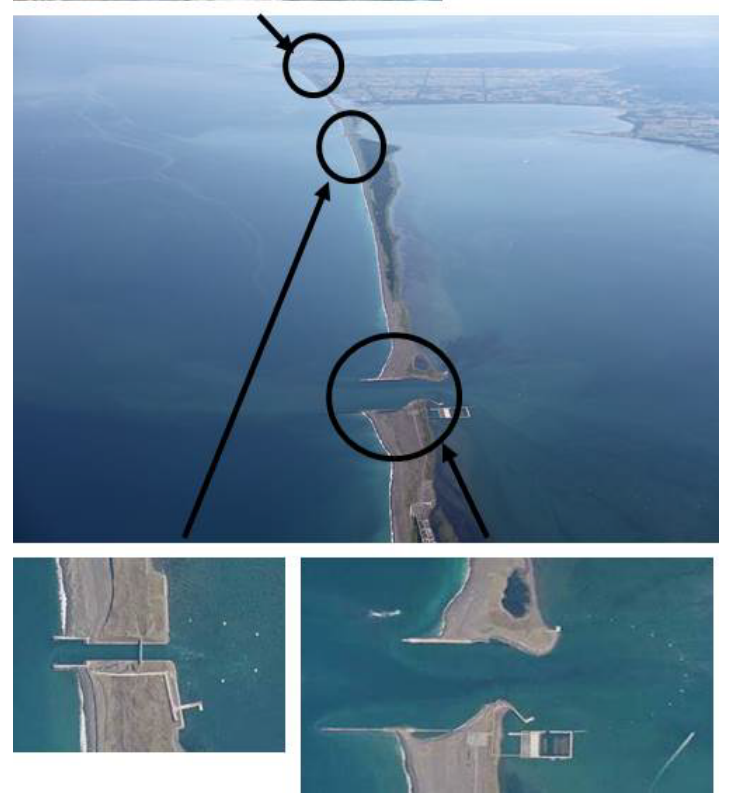

第二湖口

第一湖口

図-1 サロマ湖周辺の地形 
(a) 2000 年 11 月

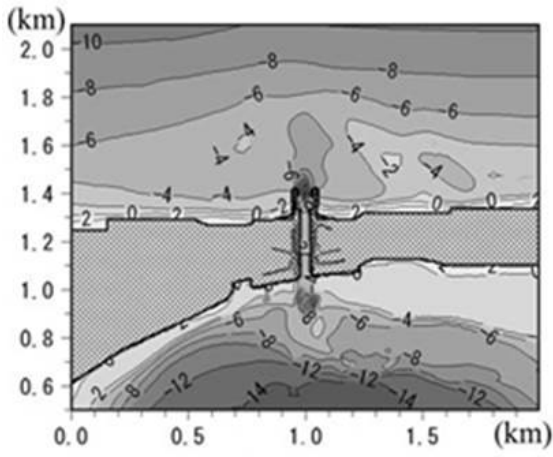

(b) 2011 年 10 月

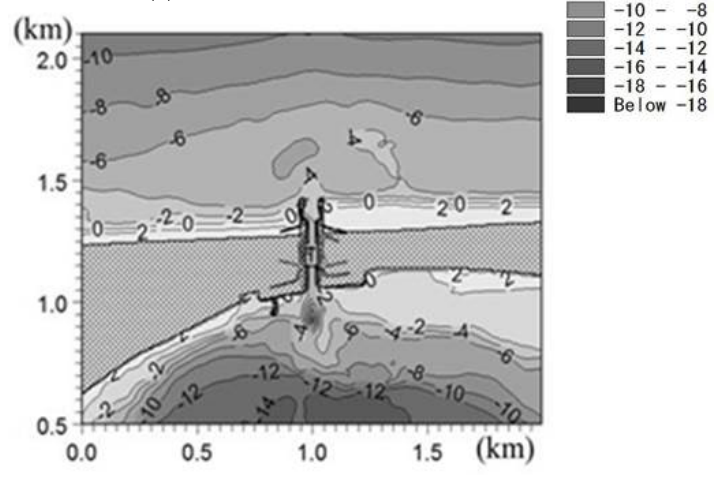

図-2 第二湖口周辺の深浅図

(1ํ単位) データのあるナウファスの紋別南（第二湖口 から西北西約 $30 \mathrm{~km}$ の水深52.6m）の2001年から2012 年を 使用した。常呂川の流出土砂量の推定には，1979年（第 二湖口開削時）～2012年の最下流の上川観測点での日平 均流量とこの期間の大洪水である1992年，2001年，2006 年洪水時の時間流量データを用いた。第二湖口周辺の底 質粒径は約 $0.3 \mathrm{~mm}$ 程度である。

\section{3. 地形変化特性と波向き別波浪エネルギー}

図-2に第二湖口周辺の深線図を示す.上側がオホーツ ク海側である。図-2(a) は最初の2000年11月, 図-2(b) は閉塞が発生する直前の2011年10月である。水路部（図 -5参照）のみ浸食防止のため水深4.5mになるようにコン クリートブロックが敷かれている. 図-2(a) 2000年では, 水路部からオホーツク海側（防砂堤間）とサロマ湖側は 強い潮流による土砂のフラッシュのため水深 $15 \mathrm{~m}$ 程度の 深掘れが形成されている. 汀線（オホーツク海側）は防 砂堤の左右岸とも防砂堤先端から $100 \mathrm{~m}$ 程度の位置にあ る. 図-2(b) 2011年10月では, 湖内側は深掘れ部もあり 2000年とほほ同じであるが，外海側は防砂堤右側汀線が 防砂堤先端付近まで前進し，防砂堤間の深掘れ部も土砂 堆積で水深 $3 \mathrm{~m}$ 以下となっている. 水路部はまだ水深 $4.5 \mathrm{~m}$ (a) 2003 年 (2002 年 11 月 2003 年 10 月)
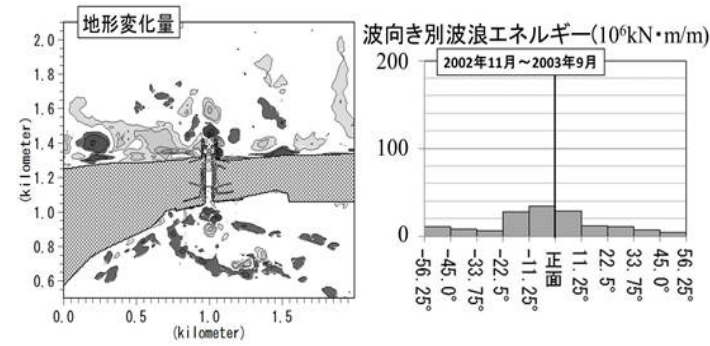

(b) 2006 年 (2005 年 10 月～ 2006 年 10 月)
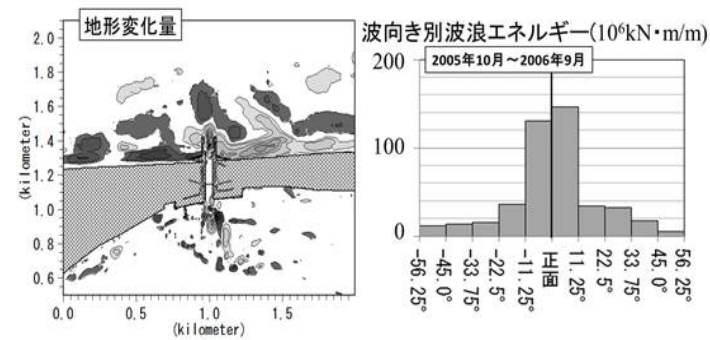

(c) 2008 年 $(2007$ 年 10 月 2008 年 10 月)

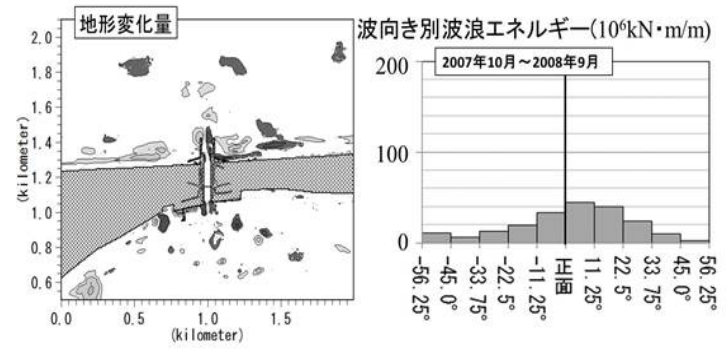

(d) 2011 年(2010 年 10 月〜2011 年 10 月)
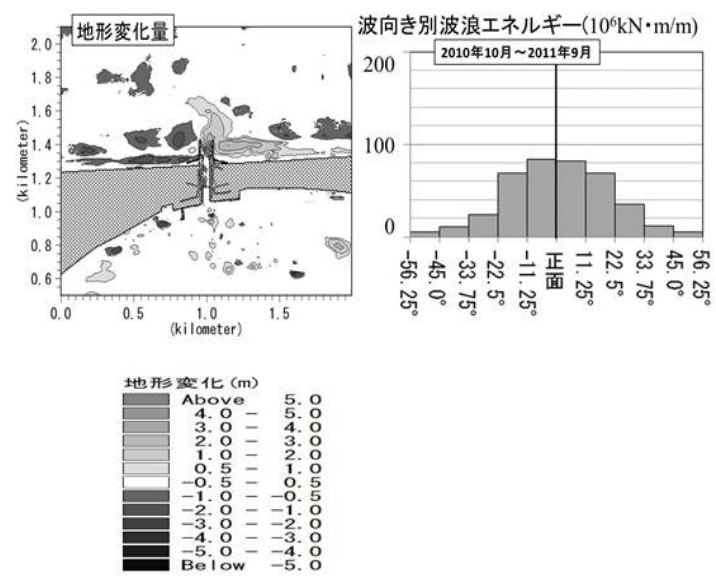

図-3 地形変化と波向別波浪エネルギー

をほぼ維持している。

以上より，2011年10月の地形は左向きの沿岸漂砂によ 
り右側汀線が防砂堤先端付近まで前進し, 沿岸漂砂が防 砂堤間の深掘れ部に流入し, 水深が浅くなった状況と推 定される。

図-3(a)〜 (d) に代表的な年の1年間の地形変化と波向 き別波エネルギーを示す。深浅測量は1年に一回10月あ るいは11月に実施されているので，その差を地形変化と した. 波浪エネルギーは深浅測量時期を考慮して波向き 別に集計している．波向き別波浪エネルギーは紋別南で 計測された波浪が第二湖口沖合でも同じ波が押し寄せる とし, 波向き正面は湖口周辺の汀線と水深 $20 \mathrm{~m}$ 等深線の 方向を考慮して決定した。

図-3(a) 2003年（2002年11月～2003年10月）は，波向 きが正面より少し左向きの波が卓越した1年間であり, 湖口左側の汀線付近に主に土砂堆積が発生している. 図 -3(b) 2006年は，図-3(a) とは逆に波向きが正面より少 し右向きに波が卓越した1年間であり, 湖口右側の汀線 付近は主に堆積が, 湖口左側の汀線付近は浸食が発生し ている. 図-3(c) 2008年は, 平均すると右向き左向きの 波が同程度であり, 汀線付近には大きな堆積, 浸食は発 生していない. 以上から, サロマ湖第二湖口周辺の沿岸 漂砂は，平均的な波向きが正面から左右に少し変化する と, 沿岸漂砂の方向まで変化するので, 精度の良い波向 き, 沿岸漂砂の把握が必要な海域である。第二湖口は防 砂堤の長さが $100 \mathrm{~m}$ と短いにもかかわらず約 30 年間一度も 閉塞が発生しなかったのは，卓越した波向きが正面から 左右に時々変化し, 長期的には沿岸漂砂量がほぼゼ口の 地点にうまく建設されたことが大きな要因と推定され る. 図-3(d) 2011年は, 図-3(b) 2006年と同様正面より 右向きの波が卓越する年で, 右側汀線付近での堆積と左 側汀線付近での浸食が発生している。すずての図は示し ていないが2009年以降は毎年防砂堤間に土砂堆積が発生 し, その結果2012年1月に第二湖口の閉塞が発生した. 図-3(b) 2006年も防砂堤間に土砂堆積が発生したが2007 年には潮流によるフラッシュにより防砂堤間は浸食が発 生している(図-5参照).

\section{4. 閉塞特性と要因}

図-3の地形変化量と波向き別波浪エネルギーの関係を より定量的に表したのが図-4である。地形変化量は図-5 の左岸汀線部の堆積量から右岸汀線部の堆積量を差し引 いた量（右向き沿岸漂砂量に関係する量）である，正味 の左入射波は，正面から左よりの入射波エネルギーの和 から右よりの入射波エネルギーの和を差し引いて求め た．図-3の説明と同様に，沿岸漂砂量に相当する地形変 化量と正味の入射波エネルギーが方向も含めてほぼ一致 していることがわかる.

図-5に地形変化の大きい4区域について，2000年を基準
とした場合の単位面積当たりの地形変化量を示す．図-6 に第二湖口左右岸の汀線位置の変化を示す。図-4, 図-5, 図-6より，2012年1月に湖口閉塞に至った周辺の地形変化 特性及び波浪特性は，次の様に推定される。まず，2006 年から2012年の7年間に右入射波の波が多く来襲し（図-4 参照), 左向きの沿岸漂砂により右岸汀線部に継続的な 土砂堆積が発生し (図-5参照), 右岸汀線が前進し防砂堤 先端に近づいている (図-6参照)。次に防砂堤間の深掘れ 部では，左向きの沿岸漂砂が防砂堤先端を超えて，2009

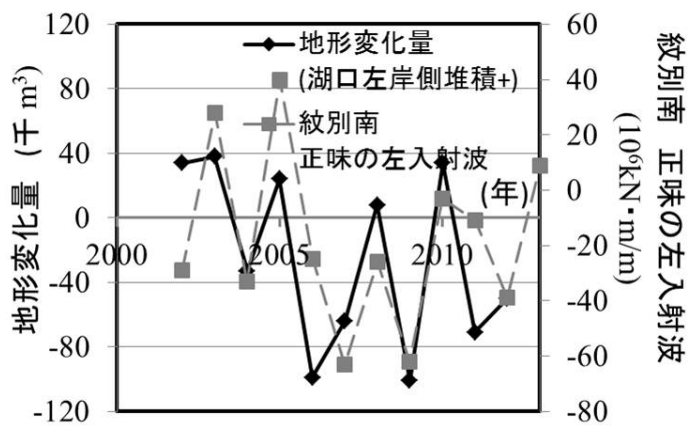

図-4 地形変化量と正味の波浪エネルギー

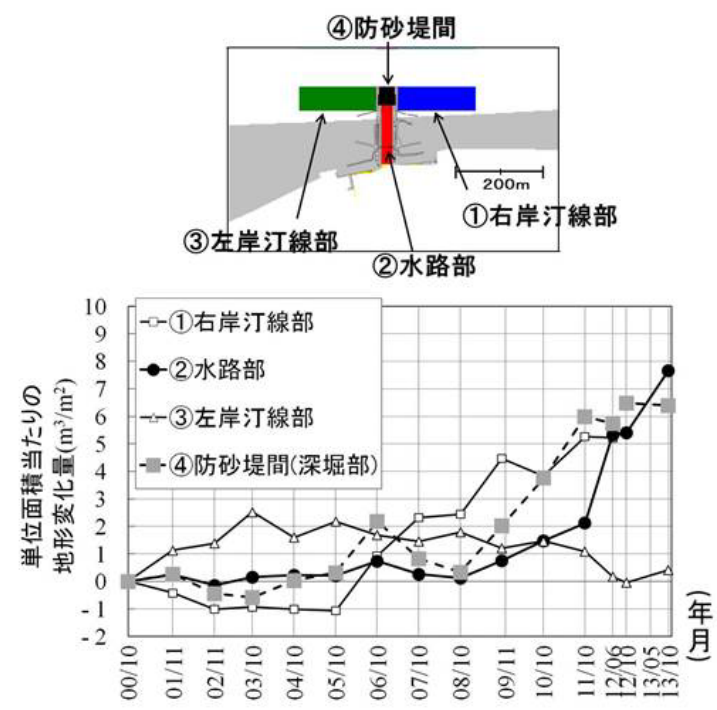

図-5 単位面積当たりの地形変化量

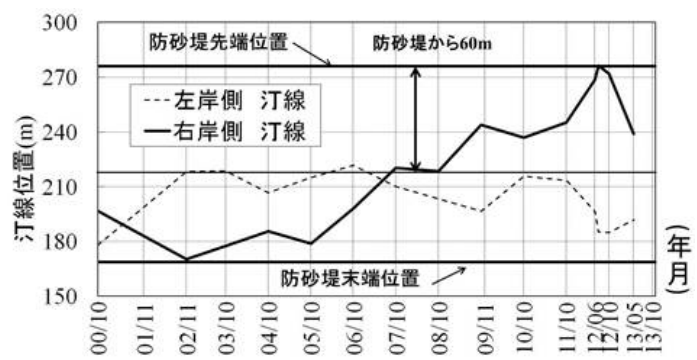

図-6 第二湖口における両岸の汀線位置の変化 


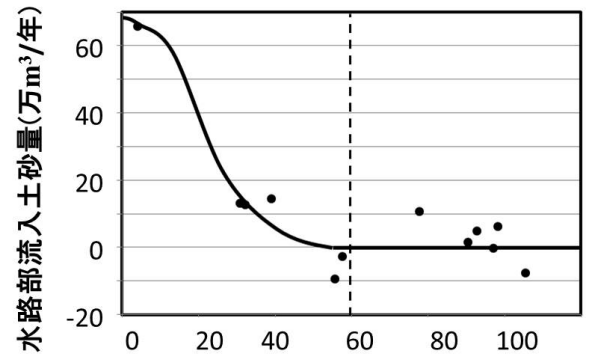

防砂堤の先端からの汀線位置(m)

図-7 水路部流入土砂量と右岸汀線位置
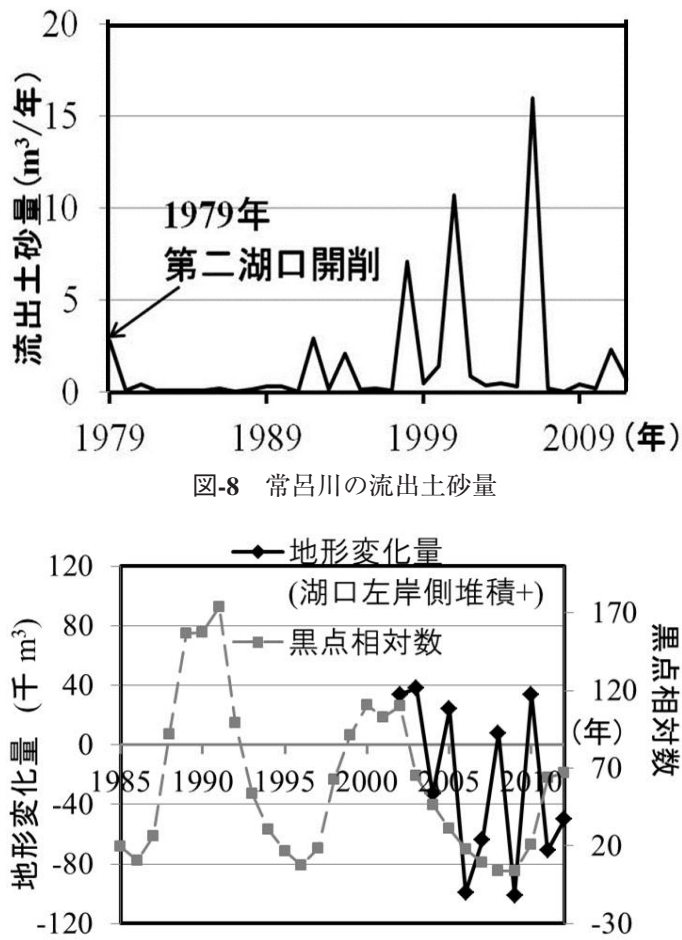

図-9 地形変化と黒点相対数

年以降継続的な土砂堆積が発生している (図-5参照)。水 路部でも2009年以降ゆっくりと土砂堆積が発生している が, 2011年10月以降急激に土砂堆積が起こり (図-5参照), 2012年1月に閉塞が発生した．2011年10月には防砂堤間 の平均水深は2000年から約 $5 \mathrm{~m}$ 減少し (図-5参照), 図-2 によると平均水深が $3 \mathrm{~m}$ 以下の浅瀬部が形成され，防砂堤 間の通水断面は水路部断面より小さくなっている. 防砂 堤の浅瀬部は, 外海からの波により水路部への土砂堆積 を促進し，さらに潮流を阻外することから潮流による土 砂の外海側へのフラッシュカを弱め, 結果として急激な 水路部への土砂堆積が発生したと推定される. 以上のよ うに, 湖口閉塞の一つの要因は右向き入射の波浪による 左向き沿岸漂砂の増加と推定される。
図-7に水路部土砂流入量と右岸汀線位置の関係を示す. 右岸汀線位置が防砂堤先端位置から60m以下になると, 水路部土砂流入量が増加し，30m以下になると急激に土 砂流入量が増加することがわかる．このことから湖口の 閉塞を防止するためには汀線位置を防砂堤先端位置から $60 \mathrm{~m}$ 以上に維持することが必要と推定される.

図-8に第二湖口が開削された1979年以降の常呂川の土 砂流出量の推定結果を示す。まず常呂川の既往1位洪水 を含む1992年，2001年，2006年の洪水時の時間流量を対 象として, 河床変動計算を実施し, 河口流出土砂量 $(\mathrm{L})$ と流量 $(\mathrm{Q})$ の関係を $\mathrm{L}=4.8 \times 10^{-10} \times \mathrm{Q}^{3.2}\left(\mathrm{~L}, \mathrm{Q}\right.$ の単位は $\mathrm{m}^{3} /$ S）を求めた. 次に, 日流量からL-Q式より年間流出土砂 量の暫定值を求め，洪水時の時間流量から算出した土砂 流出量と日流量から算出した土砂流出量の比で補正し て，1年毎の流出土砂量を推定した。常呂川の年毎の流 出土砂量は年変化が非常に大きいことがわかる。これは 数年に一回程度, 豪雨による大洪水が発生するためであ る. 長期的に見てみると，1998年以降の河口流出土砂量 は増加傾向にあることがわかる．2006年にピーク流量約 $1430 \mathrm{~m}^{3} / \mathrm{s}$ の既往1位の洪水があり，年間の河口流出土砂量 は約16.5万的になっている. 図-1の様に，常呂川の右岸汀 線部は海側にせり出した岩礁部で, 常呂川の流出土砂の 多くが河口から左側すなわち第二湖口側へ移動すると考 えられる. 以上から，1998年以降の常呂川流出土砂の増 加が, 第二湖口閉塞のもう1つの要因と考えられる.

\section{5. 土砂動態への気象変化の影響}

\section{（1）黒点相対数と地形変化量}

漂砂外力としての波向きの変化に, 影響を与えると推 定される気象要因を種々検討した結果, 黒点相対数と, 波向き変化あるいは地形変化との相関が高いことが分 かった

図-9に黒点相対数と図-4と同様の地形変化量の経年変 化を示す．地形変化量は年ごとの変動が大きいが全体的 傾向をみると黒点相対数が減少すると湖口右岸側の堆積 が増加することがわかる．地形変化量の年変動が大きい ため, この時の相関係数は 0.363 となり, 地形変化と黒点 相対数の相関はあまり強くない.

黒点相対数は太陽の黑点の数を表し,太陽の活発度 (電磁波の量) に比例する. 黒点相対数が減少（電磁波 が減少）すると，地球上に雲が発生しやすくなることが 知られており, 気象の変化, 波向きの変化, 地形変化に 影響を与えていると推定される．黑点相対数と沿岸での 気象，海象についての研究として，尾崎（1980）は, 北 海道太平洋側の浦河の冬期の西風が弱い年と太陽黒点相 対数の極小年がほぼ一致し, 約10年の周期で繰り返して いることを報告している. 
図-9からもわかる様に，黒点相対数は約11年の周期で 増減を繰り返す特徴があるため, 今後の地形変化傾向を 予測できる可能性がある。 また, 第二湖口から比較的近 い網走（東約 $30 \mathrm{~km}$ ）では1985年〜2003年の約20年間の紋 別南より長期の波高観測が実施されている．1998年以前 は波向きの直接観測が実施されておらず，波向きは天気 図から約 $20^{\circ}$ 単位で決定されている，波向きの精度が悪い ため, 5年毎の波向き別波浪エネルギーの年平均值を図 -10に示す。図-10(a) の期間は左入射波が強い傾向にあ り，図-10(b) で右入射波，図-10(c) で左入射波，図-10 （d）で右入射波が強くなるように変化することがわかる. 以上より，網走では波向きの精度がよくないが，20年間
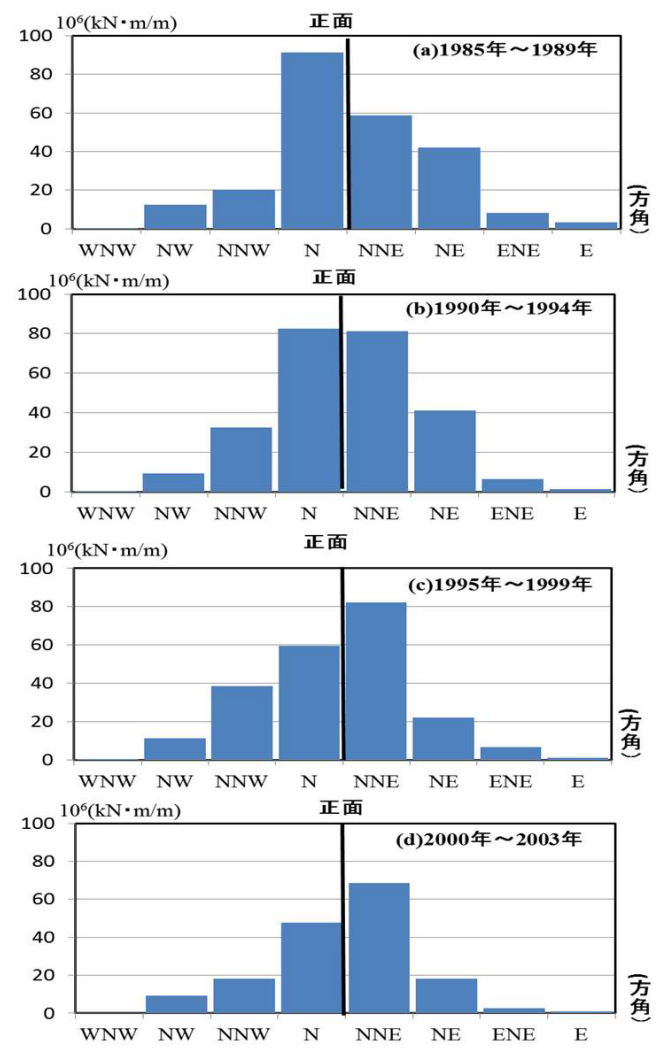

図-10 網走の5年毎の年平均波向き別波浪エネルギー
のデータより約10年周期で波向きが変化していることが 認められた。

\section{（2）温暖化に伴う雨量増加の影響}

漂砂の境界条件としての河川流出土砂量の変化への気 象要因影響については, 図-8に常呂川の流出土砂量の経 年変化を示した。図-8より，温暖化の影響でオホーツク 海側に強い降雨の発生が増加傾向で, 常呂川の流出土砂 量の増加は今後も継続すると推定される.

\section{6. おわりに}

本研究で得られた主な結果は以下の通りである.

(1)第二湖口が30年間も閉塞しなかった理由は長期的に は沿岸漂砂量がほぼゼロの波向きの変化によって沿 岸漂砂量方向の変わる位置にうまく建設されたから である。

(2)長期的に見ると, 河川流出土砂量の増加によって, 第二湖口に向かう左向きの沿岸漂砂量が増加し, 第 二湖口右側の土砂堆積が徐々に進行することが推定 される。

(3)2012年の閉塞は, (2)の長期的に右側の土砂堆積が増加 をする傾向に，短期的な 11 年周期の黒点の減少に伴う 右側の土砂堆積が加わり発生したと推定される。 2013 年以降は黒点の数は増加傾向であるので，短期的には 左入射の波が増加する可能性があり右側の土砂堆積は 減少すると推定される。

謝辞 : 本研究の一部は, 平成25年度に開催された「サロ マ湖漁港漂砂対策技術検討委員会」の成果の一部である. ここに記し，本検討会の各委員の方々に謝意を表する.

\section{参 考 文 献}

尾崎 晃（1980）：地形, 気象関係資料に基づく海浜変形の長 期予測，自然災害資料解析， 7, pp.139 150。

楠山哲弘・今 宗紀・本間明宏 - 橋本考治 - 佐々木崇之 ・ 菊 池 考 (2007)：サロマ湖第1湖口における地形変化特性 と数值解析, 海岸工学論文集, 第54巻, pp.571-575.

山上佳範 ·坂本洋一 - 河合 淳 - 藤井良昭 - 橋本孝治 - 山下 俊彦 (2012)：サロマ湖第1湖口における地形変化特性と 長期予測 モデルの構築, 土木学会論文集B2 (海岸工学), Vol.68, No.2, pp.556-560 